\title{
Advanced Rule-based Energy Management for Better Fuel Economy of Hybrid Electric Tracked Vehicle
}

Stefan V. Milićević

MSc Student University of Belgrade Faculty of Mechanical Engineering

Ivan A. Blagojević

Associate Professor University of Belgrade Faculty of Mechanical Engineering

Slavko R. Muždeka

Associate Professor University of Defence in Belgrade Military Academy
All recent technological developments in the field of power distribution in hybrid electric tracked vehicles are often hard to apply and carry high computational burden which makes them impractical for real-time applications. In this paper, a novel control strategy is proposed for parallel hybrid electric tracked vehicle based on robust and easy to implement thermostat strategy with added merits of power follower control strategy (PFCS). The goal of the control strategy is enhanced fuel economy. Serbian infantry fighting vehicle BVP M80-A is chosen as the reference vehicle. For the purpose of validation, a backward-looking, high fidelity model is created in Simulink environment. Investigation of the results indicates that the proposed control strategy offers $12.8 \%$ better fuel economy while effectively maintaining battery state of charge (SOC). Even better results (23.2\%) were achieved applying the proposed strategy to a model with an additional generator. It is concluded that further improvements can be made with combined sizing and control optimization.

Keywords: Energy Management, Hybrid Tracked Vehicle, Thermostat Strategy, Power follower strategy, Rule-based Control, Energy Efficiency.

\section{INTRODUCTION}

Hybrid propulsion systems have been very common in wheeled vehicles for many years and can be implemented in numerous ways [1]. On the other hand, few studies in the field of hybrid powertrains for military tracked vehicles have been conducted so far due to various technical and economic reasons [2]. However, in recent years, due to the increased demand for power in such vehicles, the potential benefits of fuel economy and silent-watch capabilities, as well as energy crisis, there has been a significant increase of scientific research activities on the subject matter [3-6].

Simultaneously with the research on the topic of hybridization, research was conducted on the topic of energy optimization of hybrid tracked vehicles.

In the literature [7], a genetic algorithm has been applied as a hybrid electric tracked bulldozer (HETB) energy management strategy. Validation of the obtained results was performed by HIL simulation, which showed a $6.74 \%$ fuel economy improvement compared to hybrid drive without optimization. In [8], a comparison of several machine learning-based strategies applied to a hybrid tracked vehicle was performed; the obtained data showed that the strategy based on the deep-Q learning algorithm achieved the best results, i.e. fuel economy improvement of $13.9 \%$. Strategies based on machine learning have also been analyzed in the literature [9-11] in which they have been applied to hybrid tracked vehicles. In the literature [12], a predictive strategy on HETB was applied, which

Received: April 2021, Accepted: May 2021

Correspondence to: Stefan Milićević, University of

Belgrade, Faculty of Mechanical Engineering,

Kraljice Marije 16, 11120 Belgrade 35, Serbia

E-mail: stefanm9670@gmail.com

doi:10.5937/fme2103711M

(C) Faculty of Mechanical Engineering, Belgrade. All rights reserved enabled a reduction of fuel consumption by $8 \%$, while in [4] a unique procedure of energy optimization of HETB was applied while optimizing vehicle system parameters. For optimization of energy management, a strategy based on dynamic programming (DP) was used, while for optimal sizing of vehicle subsystems the socalled bi-level optimization that combines DP and vehicle parameters optimization. In this way, a reduction in fuel consumption of as much as $16.2 \%$ was obtained. A similar procedure was performed in the literature [13] where the methods of multicriteria decision-making defined the ideal kinematic scheme, and then used the energy efficiency strategy Efficiency Evaluation Real-time Control Strategy (EERCS) which analyzes all possible power flows taking into account the speed of the vehicle, the torques achieved, the turning radius and the state of charge of the battery (SOC); after checking each possible condition, the strategy adopts the most effective one.

As can be seen, a large part of the research has included genetic algorithm and dynamic programming that represent strategies that cannot be implemented in reality $[14,15]$. To the best of authors' knowledge, the possibility of applying heuristic strategies that are very robust and easy to implement has not been analyzed so far [16]. Therefore, the topic of this paper is to define an efficient rule-based strategy for a hybrid high-speed tracked vehicle.

\section{VEHICLE MODEL}

The conceptual design of the hybrid tracked vehicle described in [6] was adopted as a reference vehicle. The mentioned conceptual solution is a hybridization model of the BVP M80-A powertrain which includes adding two electric motors and appropriate changes to the transmission (Figure 1) while keeping the existing IC 
engine (so that changes in initial hybridization were minimal). The basic characteristics of the vehicle are given in Table 1. For more information about the mentioned vehicle, as well as its conceptual design adopted as the reference model, the reader is referred to the literature $[6,17]$.

Table 1. Reference model specifications

\begin{tabular}{|l|c|}
\hline \multicolumn{1}{|c|}{ Parameter } & Value \\
\hline Vehicle weight & $13850 \mathrm{~kg}$ \\
\hline Track width & $2.526 \mathrm{~m}$ \\
\hline Contacting track length & $3.3 \mathrm{~m}$ \\
\hline Rolling resis. coeff. & 0.07 \\
\hline Sprocket radius & $0.2577 \mathrm{~m}$ \\
\hline IC Engine power & $235 \mathrm{~kW} @ 2500 \mathrm{rpm}$ \\
\hline Electric motor & $2 \times 60 \mathrm{~kW}, 1800 \mathrm{rpm}$ \\
\hline Battery & $460 \mathrm{~V}, 54 \mathrm{Ah}$ \\
\hline
\end{tabular}

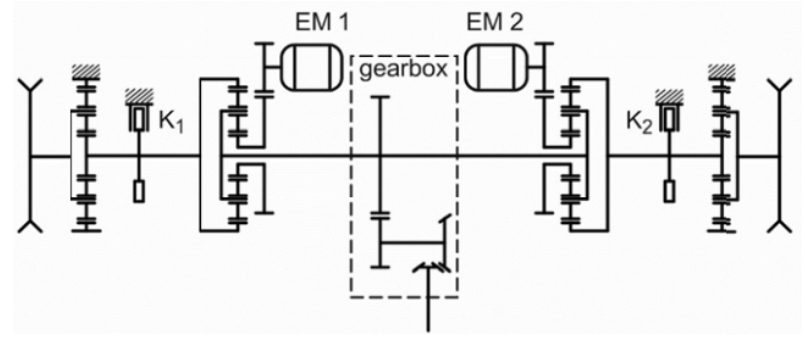

Figure 1. Kinematic scheme of hybrid drive system

\subsection{Calculation of the power requirement}

The foundations of tracked vehicle dynamics were laid in the middle of the last century in [18]. A re-synthesis of available knowledge was published in [19]. In recent times, processes that occur during the interaction of the track and terrain are often taken into account [20-22]. However, such problems must be solved numerically, which is very demanding in terms of the computational time. Therefore, in this paper, a model was adopted that considers only the longitudinal, lateral, and yaw movements on a flat surface while neglecting the centrifugal force. The model is described by the equations from [19]:

$$
\begin{gathered}
m \frac{d^{2} s}{d t^{2}}=F_{o}+F_{i}-R_{t o t} \\
I_{z} \frac{d^{2} \theta}{d t^{2}}=\frac{B}{2}\left(F_{o}-F_{i}\right)-M_{r} \\
M r= \begin{cases}0 \quad, d \theta / d t=0 \\
\frac{\mu m g L}{4} & , \quad d \theta / d t \neq 0\end{cases}
\end{gathered}
$$

where $F_{O}$ and $F i$ are the thrusts of outside and inside tracks, $R_{\text {tot }}$ and $\mathrm{Mr}$ are the total longitudinal and yaw motion resistances, $L$ is the contact track length, $\theta$ is the heading angle of the vehicle, $B$ is the track width, $I_{z}$ the moment of inertia, $m$ is the vehicle mass, and $\mu$ is the coefficient of lateral resistance.

Coefficient $\mu$ is calculated based on the empirical expression [23]:

$$
\mu=\frac{\mu_{\max }}{a+(1-a)\left(\frac{R}{B}+\frac{1}{2}\right)}
$$

where $\mu_{\max }$ is the maximum value of coefficient of lateral resistance, $a$ is the experimental coefficient, and $R$ is the turning radius.

Power required can be defined as:

$$
P_{z a h}=R_{t o t} \cdot \bar{V}+M r \cdot \omega
$$

where $\bar{V}$ is the speed of the center of gravity of the tracked vehicle, and $\omega$ is the angular speed.

Efficiency from the sprockets to the tracks is calculated as follows:

$$
\eta_{g m}=0.95-0.018 \cdot V
$$

where $V$ is the vehicle speed.

\subsection{Engine model}

The quasi-static model with no transient dynamics was adopted [24]. Fuel consumption is defined as:

$$
\frac{d m_{f}}{d t}=f\left(T_{e}, n_{e}\right)
$$

where $T_{e}$ and $n_{e}$ are effective torque and rotational speed of the engine.

Total consumption is:

$$
C=\int_{0}^{t} d m_{f}
$$

The ICE model is based on a fuel map of reference vehicle (Figure 2) [25].

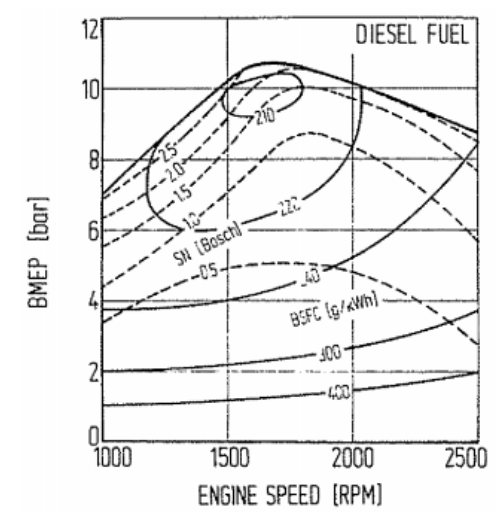

Figure 2. Fuel map contour of ICE (g/kWh)

\subsection{Modeling electric motors and battery}

The power of electric motor is calculated as:

$$
P=U \cdot I
$$

where $U$ and $I$ are voltage and current.

Motor efficiency is a function of torque and angular velocity of the electric motor: 


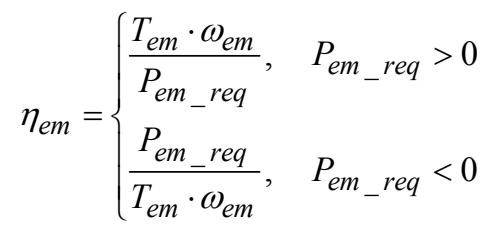

where $P_{e m} r e q$ is the required power, while $T_{e m}$ and $\omega_{e m}$ are the torque and angular speed of the electric motor.

Due to the interdependence between the electric motor and the battery, the torque of the electric motor is defined as:

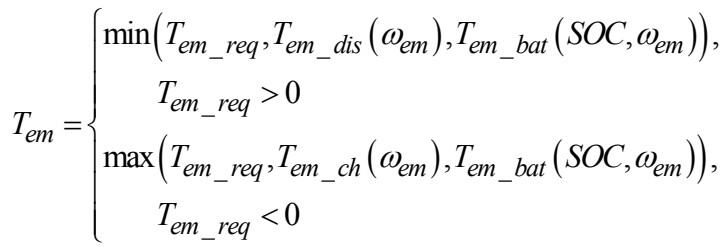

where $T_{\text {em_req }}$ is the required torque (load), $T_{e m_{-}}$ch and $T_{e m}$ dis are the maximum motor torque in motoring and generating modes, $T_{\text {em_bat }}$ is the torque limit due to the battery current limits during charging and discharging.

The battery model ignores the effects of aging and heating. The battery is represented by a simple electrical circuit (Figure 3), and the batter state of charge is defined as:

$$
S O C=-\frac{V_{o c}-\sqrt{V_{o c}^{2}-4\left(R_{\mathrm{int}}+R_{t}\right) \cdot T_{e m} \cdot \omega_{e m} \cdot \eta_{e m}^{-\operatorname{sgn}\left(T_{e m}\right)}}}{2\left(R_{\mathrm{int}}+R_{t}\right) \cdot Q_{b a t}}
$$

where $V_{o c}$ is the open circuit voltage, $R_{\text {int }}$ is the internal resistance, $R_{t}$ is the terminal resistance, $Q_{b a t}$ is the maximum battery charge.

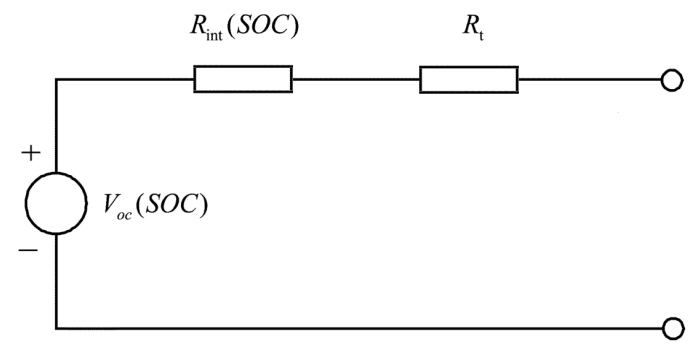

Figure 3. Equivalent battery circuit model

\section{PROPOSED ENERGY MANAGEMENT STRATEGY}

In the literature [6] which refers to the reference conceptual design of a hybrid tracked vehicle, the control strategy is not unambiguously defined. The research focus was functional feasibility and the achieved performance of the hybrid drive while energy efficiency was not a priority. However, the idea that electric motors work only during turning motion is clearly stated. Given that the rated power of electric motors is $60 \mathrm{~kW}$ each, it is clear that the energy of the electric motors is not fully utilized. Therefore, a new energy management strategy was proposed based on the following premises:

- minimize the fuel consumption

- effectively harness regenerative braking energy

- maintain the battery state of charge within a predefined range

- maintain the engine operating point in an energy-efficient area

The input parameters of the model are vehicle acceleration, vehicle speed, and battery state of charge (SOC). After processing input parameters, the strategy selects the appropriate operating mode.

\subsection{Operating modes}

Operating modes can be classified into three groups as shown in Table 2.

Table 2. Operating modes

\begin{tabular}{|l|l|}
\hline \multirow{3}{*}{ Pure traction } & EM - electric only \\
\cline { 2 - 2 } & E - engine only \\
\cline { 2 - 2 } Traction + Charge & $\begin{array}{l}\text { EB - hybrid mode } \\
\text { traction and charging }\end{array}$ \\
\hline Charge & RB - regenerative braking \\
\hline
\end{tabular}

EM: In this mode, traction is enabled exclusively by electric motors. If the battery SOC is in a predefined range, the control strategy compares the desired vehicle speed with the predefined speed threshold for the EM mode.

E: When it is not realistically possible to significantly improve vehicle performance and energy efficiency, the control strategy activates $\mathrm{E}$ mode in which the vehicle is powered exclusively by the engine while the battery SOC is saved.

HM: In this mode, the vehicle is powered by both the engine and electric motors. The control strategy selects the speeds of both the electric motor and the engine so that the operating point of the engine is maintained in the most efficient operating range at all times. It is possible to select several engine speeds for one specific desired vehicle speed due to the existence of a planetary gear in the transmission (Figure 4). This mode is the main difference between the proposed and the reference model strategy. The largest share of fuel economy improvement is expected to come from this mode provided the fact that it is supposed to be the most frequent of all modes due to the large speed range.

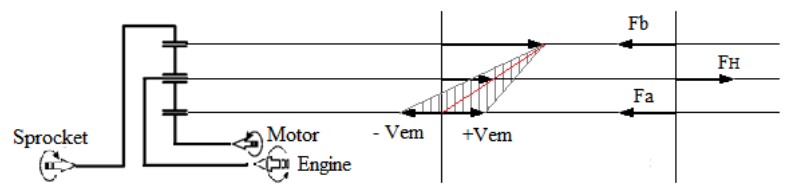

Figure 4. Possibility of engine speed control via electric motors

Figure 4 shows the essence of the motor-assist strategy. With a ring gear speed acting as a constraint (desired output speed), with the adequate control of the sun gear speed it is possible to achieve a large range of speeds of the carrier. The middle line represents the current speed profile of the planetary gear set elements, 
while the possible speed range of the sun gear and the corresponding carrier speed is shaded. By further increasing the speed range of the sun gear it is possible to provide even greater flexibility of the hybrid drive.

The control strategy works by discretizing the range of possible speeds of all three elements of the planetary gear set. Then, for each of the possible combinations (candidates), the most efficient one is determined (Figure 5).

EB: In this mode, the vehicle is power solely by the engine while electric motors act as generators driven by the engine. In this way, both traction and SOC maintaining are achieved. This mode is activated when the battery SOC reaches a value of 0.45 and lasts until the SOC reaches a value of 0.60 when it is deactivated as shown by the algorithm (Figure 6).

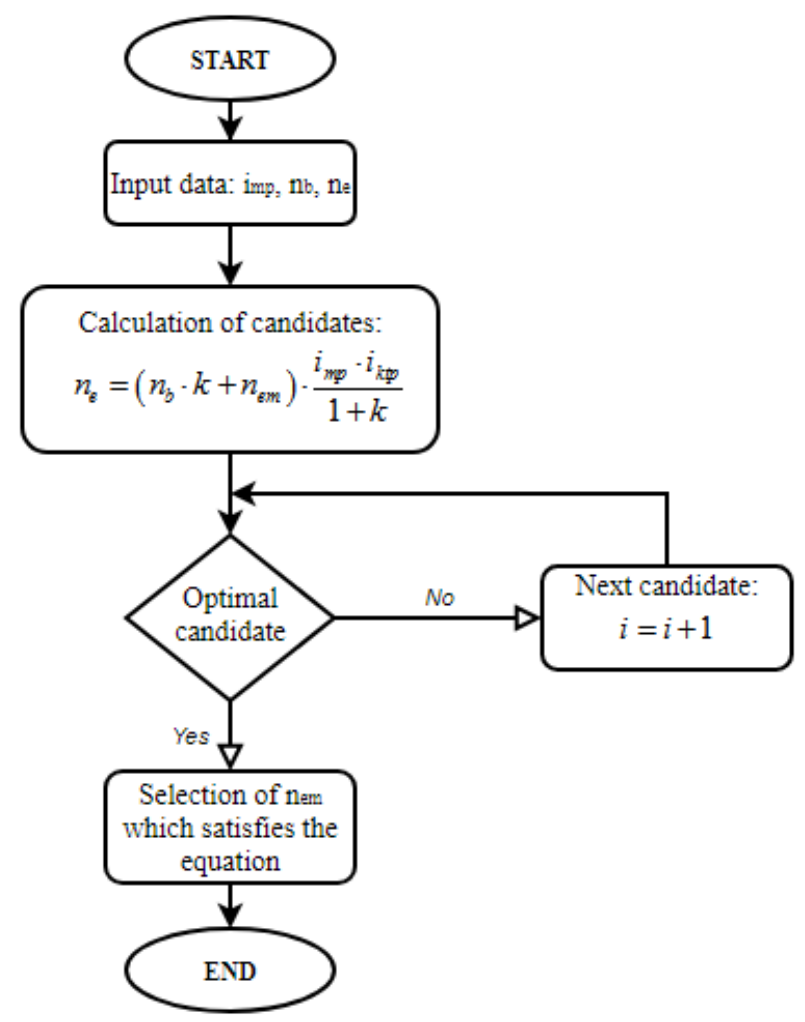

Figure 5. HM operating mode algorithm

RB: During braking, the regenerative braking mode is activated, which uses the kinetic energy of the vehicle and recharges the battery.

Table 3. Possible states with corresponding operating modes

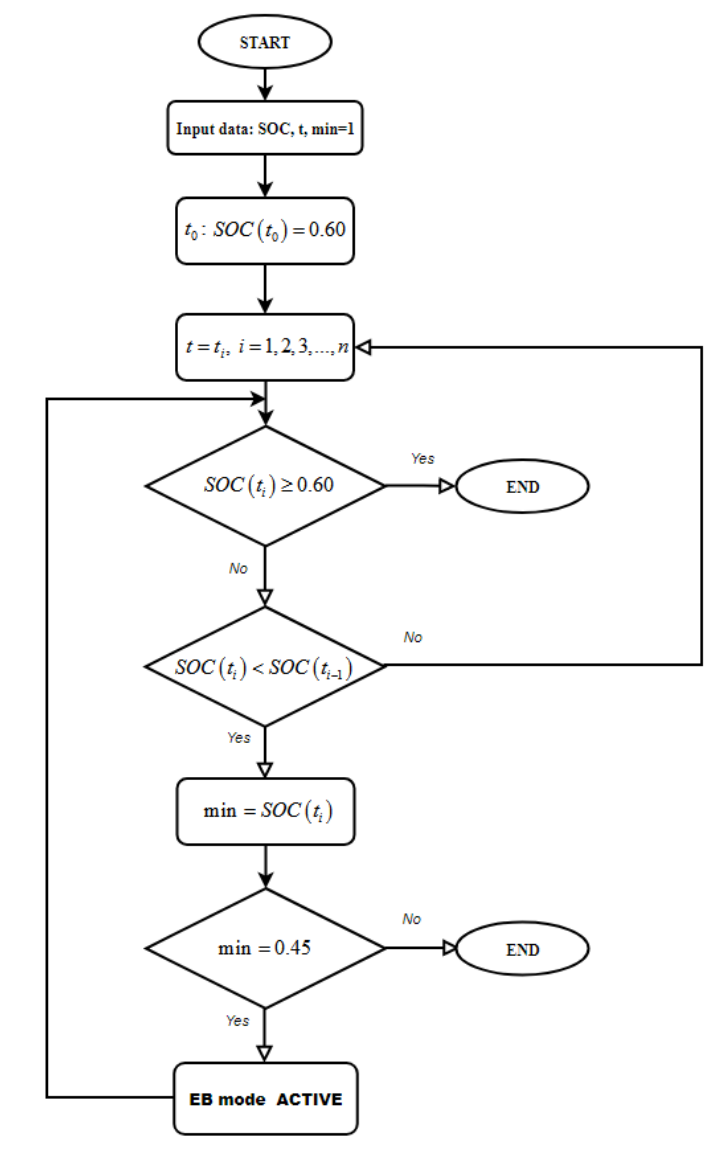

Figure 6. EB operating mode algorithm

\subsection{Rule-based control}

The proposed strategy is based on the thermostat strategy but incorporates elements of power follower strategy (PFCS) in hybrid mode (HM) as a tool for energy-efficient operation of IC engine.

The power follower part of the strategy was used in only one operating mode where, based on the motorassist model, the operating point of the engine is maintained in an energy-efficient range.

The thermostat part of the strategy is thresholdbased, i.e. it is based on an on/off mechanism where the decision on whether a particular mode will be active or not is made based on the accuracy of certain conditions.

All conditions can be true or false depending on the current state value and the predefined threshold value. Operating modes are selected based on the current functional state in accordance to Table 3.

\begin{tabular}{|c|c|c|c|c|c|c|c|}
\hline \multirow{2}{*}{ No. } & \multirow{2}{*}{$\begin{array}{c}\text { Operating } \\
\text { mode }\end{array}$} & $\begin{array}{c}\text { Acceleration } \\
\text { state }\end{array}$ & \multicolumn{4}{|c|}{ Battery state of charge } & \multicolumn{2}{c|}{ Speed state } \\
\cline { 3 - 8 } & & $\mathrm{a}(\mathrm{t}) \geq 0$ & $\mathrm{SOC}(\mathrm{t}) \geq 0.45$ & $\mathrm{~min}=0.45$ & $\mathrm{SOC}(\mathrm{t}) \leq 0.60$ & $\mathrm{~V}(\mathrm{t}) \leq 10$ & $\mathrm{~V}(\mathrm{t}) \geq 50$ \\
\hline 1 & $\mathrm{EM}$ & + & + & - & \pm & - & + \\
\hline 2 & $\mathrm{E}$ & + & + & - & \pm & - & - \\
\hline 3 & $\mathrm{HM}$ & + & + & - & + & \pm & \pm \\
\hline 4 & $\mathrm{~EB}$ & + & + & + & + & \pm \\
\hline 5 & $\mathrm{RB}$ & - & \pm & \pm & \pm & \pm \\
\hline "+" state is correct (true); "-" state is not correct (false); " \pm " correctness of state is irrelevant for given mode; \\
"min" the minimum value of battery SOC in time range where SOC [0.45,0.60]
\end{tabular}


Based on the functional states, it is possible to construct a set of rules (Table 4) based on which the operating modes are updated during the simulation in accordance with instantaneous values of input parameters.

Table 4. Set of rules for proposed strategy

\begin{tabular}{lcccc}
\hline OM & \multicolumn{4}{c}{ Rule } \\
\hline EM & $\mathrm{a}(\mathrm{t}) \geq 0$ & SOC $(\mathrm{t}) \geq 0.45$ & $\mathrm{~V}(\mathrm{t}) \leq 10$ & $\min \neq 0.45$ \\
E & $\mathrm{a}(\mathrm{t}) \geq 0$ & SOC $(\mathrm{t}) \geq 0.45$ & $\mathrm{~V}(\mathrm{t}) \geq 50$ & $\min \neq 0.45$ \\
HM & $\mathrm{a}(\mathrm{t}) \geq 0$ & SOC $(\mathrm{t}) \geq 0.45$ & $10<\mathrm{V}(\mathrm{t})>50$ & $\min \neq 0.45$ \\
EB & \multicolumn{5}{c}{$\mathrm{a}(\mathrm{t}) \geq 0 \quad \mathrm{SOC}(\mathrm{t}) \leq 0.60$} & $\min =0.45$ \\
RB & \multicolumn{5}{c}{$\mathrm{a}(\mathrm{t})<0$} \\
\hline
\end{tabular}

The hierarchical organization of the possible functional states by the degree of importance can be observed from Table 3 and Table 4 as follows:

The state of acceleration is hierarchically the most important and enables efficient use of regenerative braking energy.

The state of SOC that enables efficient conservation of electricity.

Minimum SOC value in the predefined range that allows easy energy management in the SOC range in which several operating modes are possible as shown in Figure 7.

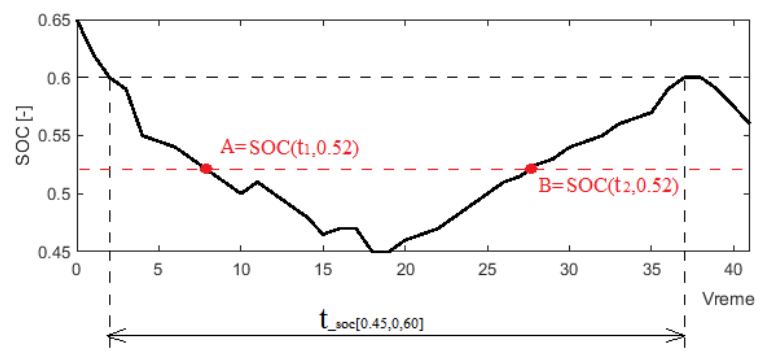

Figure 7. Operating mode selection problem at SOC $\epsilon$ $(0.45,0.60)$

The SOC value at points A and B is the same (Figure 7), but the operating mode is not the same even though both acceleration and speed have the same values. At point $\mathrm{A}$, one of the three traction modes is active depending on the other conditions, while at point $B$ the traction+charge mode is active with the battery being recharged to the desired upper limits. Therefore, it was necessary to introduce another functional state on the basis of which the current mode of operation can be determined. This supplementary state is the minimum SOC value on the range. If the condition is met then EB mode is active.

The speed state is hierarchically the least important and serves to determine one of the traction modes when all other states are met.

\section{RESULTS AND DISCCUSION}

Based on the mathematical model, a backward-looking model was created in the Simulink environment shown in Figure 8.

Unlike wheeled vehicles, a small number of recorded tracked driving cycles are available in the literature. The only requirement when creating a driving cycle for tracked vehicles is that in addition to the vehicle speed, the cycle must also contain turning data. Therefore, the driving cycle shown in Figure 9 is formed. The drive cycle includes significant acceleration, braking, and steering. The average vehicle speed is $18.5 \mathrm{~km} / \mathrm{h}$, and travel distance is $11.12 \mathrm{~km}$.

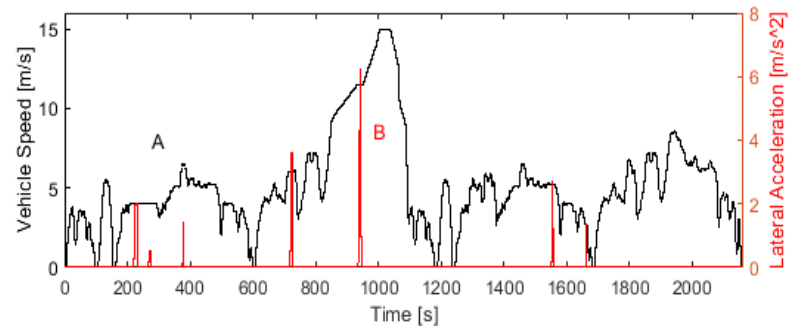

Figure 9. Drive cycle A) Speed, B) Lateral acceleration

The proposed control model has proven to be a very efficient motor-assist mechanism that significantly balances the operation of the engine allowing constant operation of the engine at a speed of about $1400 \mathrm{rpm}$ despite the oscillations of the vehicle speed (Figure 10). The operation of the engine in the speed range of approximately $1400 \mathrm{rpm}$ is very efficient as can be seen in Figure 2.

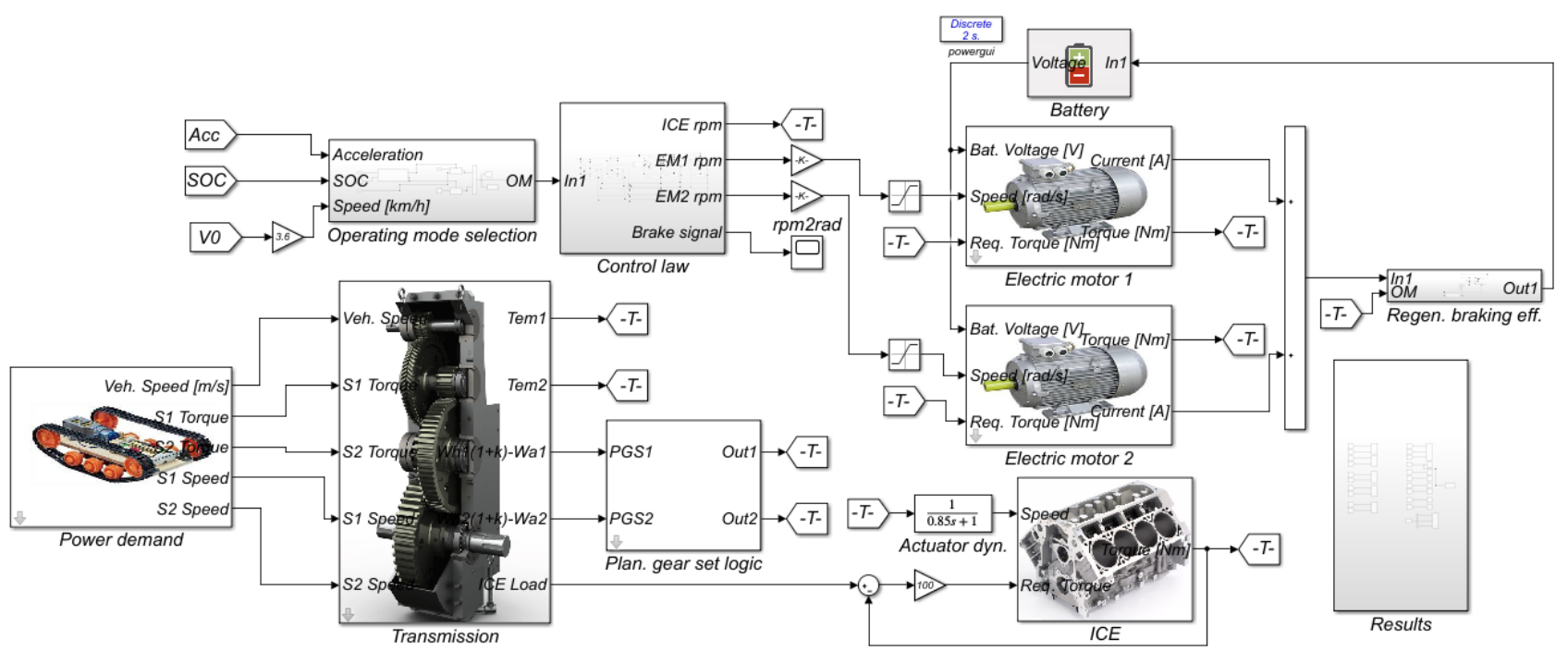

Figure 8. Vehicle model in Simulink 


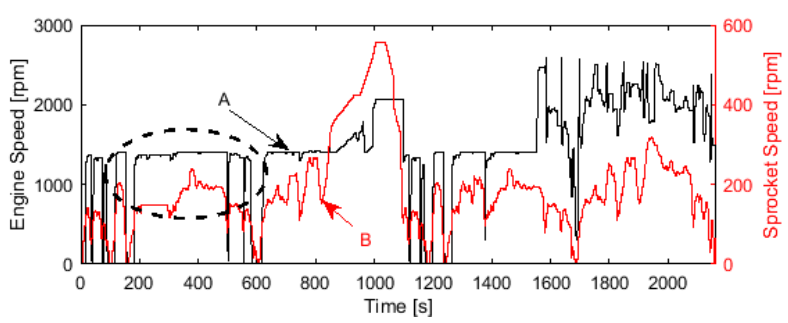

Figure 10. Engine (A) and Sprocket (B) speed profiles

Table 5 shows the percentage share of individual modes during the driving cycle.

Table 5. Share of simulation time between modes

\begin{tabular}{|c|c|}
\hline Operating mode & \% of simulation time \\
\hline EM & $8.61 \%$ \\
\hline E & $2.10 \%$ \\
\hline HM & $42.81 \%$ \\
\hline EB & $10.82 \%$ \\
\hline RB & $35.66 \%$ \\
\hline
\end{tabular}

The hypothesis that the HM will be the most prevalent has been confirmed. Also, from the percentage share of the RB mode, it is clear why it is essential to efficiently use regenerative braking energy.

In the part of Figure 10 marked with the dashed line, it can be seen that the engine speed is constant despite the significant change in the sprocket wheel speed. This trend continues during the simulation until the time mark of about 1600 seconds when the speed of the engine starts to oscillate together with the sprocket speed. This occurs due to the vehicle entering the EB mode. In this mode the engine is forced to compensate for any change in the desired vehicle speed due to the predefined speed of the electric motor in generating mode. This is reflected in increasing specific fuel consumption in that part of the diagram (Figure 11). In the last quarter of the simulation, the fuel consumption is higher compared to the reference vehicle due to the necessary increase in the speed of the engine, which is illustrated in Figure 12.

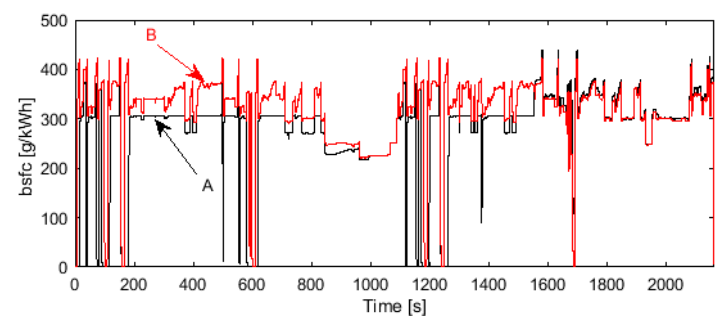

Figure 11. Brake specific fuel consumption A)Proposed model, B)Reference vehicle

In the reference vehicle model [6], the electric motors only work when turning, which means that rotors are kept stationary most of the time in order to keep the sun gear of the planetary gear set locked. In the proposed control strategy described in this paper, in EB mode, when recharging the batteries, the electric motors maintain a constant speed of "negative" sign $\left(n_{E M}\right)$, which allows them to work in generating mode. According to Figure 10, the engine must compensate for this speed of the electric motor in order to maintain the desired vehicle speed. a)

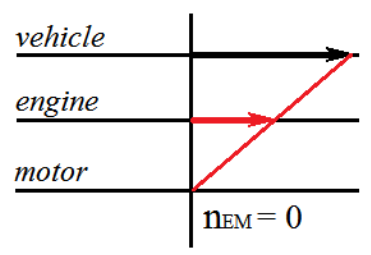

b)

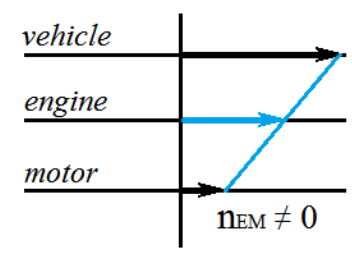

Figure 12. Illustration of the difference between the required speed of the engine (carrier) in a) the reference vehicle and $b$ ) the proposed model

In addition to the unfavorable speed, the torque of the engine is quite low for most of the simulation time (Figure 13A), which has a very unfavorable effect on the specific fuel consumption. The increase of the battery SOC is quite slow, as shown in Figure 14A. With the conventional drivetrain of BVP M80-A, the engine is designed to provide the required torque in all driving modes, including turning motion where the resistances are significantly higher compared to straightline motion. Therefore, the engine is designed according to the maximum load, which in the reference model presented in [6] is significantly less because the electric motors take over the entire load of the auxiliary drive (sun gear) when turning.

Further reduction of fuel consumption can be achieved by reducing the power of the IC engine, which would bring the operating point of the engine closer to the efficient operating range. Besides that, there is a sound possibility of installing a generator powered by the engine, which would avoid the need for engine downsizing while eliminating the fuel-inefficient EB mode and simplifying the control algorithm.

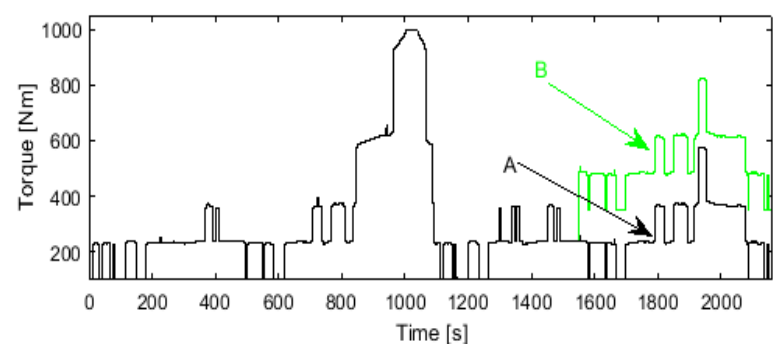

Figure 13. Engine torque A) Without generator, B) With generator

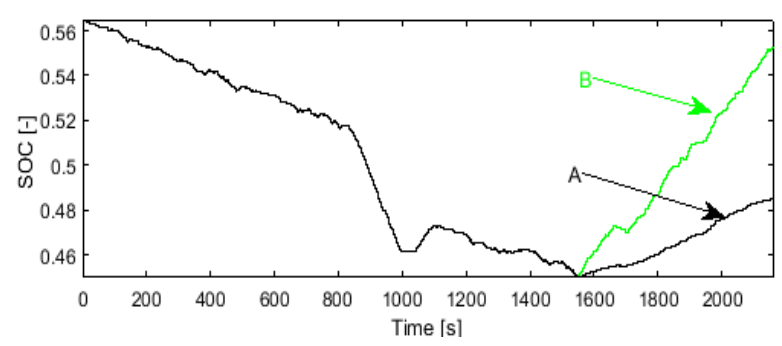

Figure 14. Battery SOC A) Without generator, B) With generator 


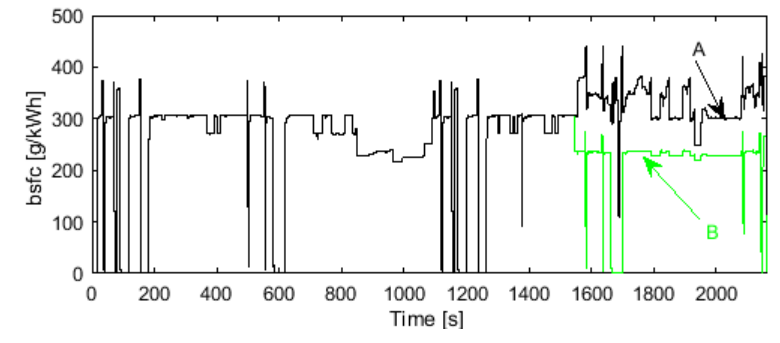

Figure 15. Brake specific fuel consumption A) Without generator, B) With generator

For comparison, a model was created with a generator that activates when the EB mode starts in the proposed model. The results showed that the following was achieved with the generator model:

1. much faster increase of battery SOC

2. lower fuel consumption due to more efficient operation of the engine

3. simplification of an energy management algorithm that now has one functional state less A comparison of the model's parameters without (A) and with (B) a generator is shown in Fig. 13 to Fig. 15.

An overview of the achieved fuel economy improvement is shown in Table 6.

Table 6. Fuel consumption comparison

\begin{tabular}{|l|c|c|}
\hline \multicolumn{1}{|c|}{ Control strategy } & $\begin{array}{c}\text { Relative fuel } \\
\text { consumption }\end{array}$ & $\begin{array}{c}\text { Improvement } \\
{[\%]}\end{array}$ \\
\hline Ref. model [6] & 100 & - \\
\hline Proposed model & 87.2 & $\mathbf{1 2 . 8}$ \\
\hline $\begin{array}{l}\text { Model with } \\
\text { generator }\end{array}$ & 76.8 & $\mathbf{2 3 . 2}$ \\
\hline
\end{tabular}

\section{CONCLUSION}

The application of a novel rule-based strategy was presented in this paper. The proposed strategy combines thermostat and power follower strategies and is threshold-based and easy to implement. Mathematical models of vehicle and control strategy were validated via high fidelity Simulink model. As a result, the proposed strategy achieved fuel economy increase of $12.8 \%$ compared to the reference vehicle. Such improvement is remarkable considering its simple nature and easy implementation. However, this simplicity compromises strategy performance during charge sustaining mode. It is shown that, during SOC maintaining operation engine operating point drifts away from most efficient region of operation.

In order to eliminate this disadvantage, a model with generator was proposed and implemented. Simulation results showed fuel economy increase of $23.2 \%$ compared to the reference model with very effective battery SOC sustaining and further simplification of control algorithm. This kind of performance has not been claimed by any other known rule-based strategy but feasibility questions arise as generator was not provided by the reference model.

In addition, it was concluded that fuel consumption could be reduced by downsizing the engine, which remained unchanged despite the installation of two electric motors with a total power of $120 \mathrm{~kW}$. Therefore, it is clear that the best optimization results can be achieved by simultaneously optimizing the system parameters and the control algorithm.
Further improvements to the proposed strategy can be made, namely by applying one of the optimization strategies in hybrid mode of operation. The applied optimization strategy would not carry high computational burden as it is exempt of battery SOC constraints.

\section{REFERENCES}

[1] Blagojević, I. A., Mitić, S. R., Stamenković, D. D., \& Popović, V. M.: The future (and the present) of motor vehicle propulsion systems, Thermal Science, Vol. 23, No. 5, pp. 1727-1743, 2019.

[2] Khalil, G.: Challenges of hybrid electric vehicles for military applications, in: 2009 IEEE Vehicle Power and Propulsion Conference (pp. 1-3), 2009.

[3] Taira, H., Yoshikawa, T., \& Jumonji, K.: Development of Tracked Combat Hybrid-Electric Vehicle, Ministry of Defense of Japan, 2017.

[4] Zou, Y., Sun, F., Hu, X., Guzzella, L., \& Peng, H.: Combined optimal sizing and control for a hybrid tracked vehicle, Energies, Vol. 5(11), pp. 46974710, 2012.

[5] Zou, Y., Sun, F. C., Zhang, C. N., \& Li, J. Q.: Optimal energy management strategy for hybrid electric tracked vehicles, International Journal of Vehicle Design, Vol. 58(2-4), pp. 307-324, 2012.

[6] Milićević, S. V., \& Muždeka, S. R.: Modelling and performance analysis of the BVP M-80A hybrid drive, Vojnotehnički glasnik, Vol. 69(1), pp. 64-87, 2021.

[7] Wang, H., Song, Q., Wang, S., \& Zeng, P.: Dynamic modeling and control strategy optimization for a hybrid electric tracked vehicle, Mathematical Problems in Engineering, Volume 15, pp. 1-12, 2015.

[8] Han, X., He, H., Wu, J., Peng, J., \& Li, Y.: Energy management based on reinforcement learning with double deep Q-learning for a hybrid electric tracked vehicle, Applied Energy, Vol. 254, Article 113708, 2019.

[9] Liu, T., Zou, Y., Liu, D., \& Sun, F.: Reinforcement learning of adaptive energy management with transition probability for a hybrid electric tracked vehicle, IEEE Transactions on Industrial Electronics, Vol. 62(12), pp. 7837-7846, 2015.

[10] Liu, T., Zou, Y., Liu, D., \& Sun, F.: Reinforcement learning-based energy management strategy for a hybrid electric tracked vehicle, Energies, Vol. 8(7), pp. 7243-7260, 2015.

[11]Zou, Y., Liu, T., Liu, D., \& Sun, F.: Reinforcement learning-based real-time energy management for a hybrid tracked vehicle, Applied energy, 171, 372382, 2016.

[12] Wang, H., Huang, Y., Khajepour, A., \& Song, Q.: Model predictive control-based energy management strategy for a series hybrid electric tracked vehicle, Applied Energy, Vol. 182, pp. 105$114,2016$.

[13] Qin, Z., Luo, Y., Zhuang, W., Pan, Z., Li, K., Peng, 
H.: Simultaneous optimization of topology, control and size for multi-mode hybrid tracked vehicles, Applied energy, Vol. 212, pp. 1627-1641, 2018.

[14] Panday, A., \& Bansal, H. O.: A review of optimal energy management strategies for hybrid electric vehicle, International Journal of Vehicular Technology, Vol. 2014, Article 160510, pp 1-12. 2014.

[15] Zhang, W., Wang, J., Du, S., Ma, H., Zhao, W., \& Li, H.: Energy management strategies for hybrid construction machinery: Evolution, classification, comparison and future trends, Energies, Vol. 12(10), 2019.

[16] Huang, Y., Wang, H., Khajepour, A., He, H., \& Ji, J.: Model predictive control power management strategies for HEVs: A review, Journal of Power Sources, Vol. 341, pp. 91-106, 2017.

[17] Vesić, M., \& Muždeka, S.: Analysis of influence of turning system kinematic scheme on turning power balance for high speed tracked vehicles, Vojnotehnički glasnik, Vol. 55(2), pp. 149-168, 2007.

[18] Bekker, M. G.: Theory of land locomotion, University of Michigan Press, 1956.

[19] Wong, J. Y.: Theory of ground vehicles, John Wiley \& Sons, 2008.

[20] van Wyk, D. V., Spoelstra, J., de Klerk, J. D.: Mathematical modelling of the interaction between a tracked vehicle and the terrain, Applied mathematical modelling, Vol. 20(11), pp. 838-846, 1996.

[21] Maclaurin, B.: A skid steering model using the Magic Formula, Journal of Terramechanics, Vol. 48(4), pp. 247-263, 2011.

[22] Wong, J. Y., Garber, M., \& Preston-Thomas, J.: Theoretical prediction and experimental substantiation of the ground pressure distribution and tractive performance of tracked vehicles, in: Proceedings of the Institution of Mechanical Engineers, Part D: Transport Engineering, 198(4), pp. 265-285, 1984.

[23] Nikitin, A. O., Sergeev, L. V., 1962. Tank Theory, Order of Lenin Military Armored Academy, Moscow, 1962. (in Russian)
[24] Liang, J. Y., Zhang, J. L., Zhang, X., Yuan, S. F., \& Yin, C. L.: Energy management strategy for a parallel hybrid electric vehicle equipped with a battery/ultra-capacitor hybrid energy storage system, Journal of Zhejiang University Science A, Vol. 14(8), pp. 535-553, 2013.

[25] Hardenberg, H. O., Buhl, H. W.: The MERCEDESBENZ OM 403 VA-A Standard Production, Compression-Ignition, Direct-Injection Multifuel Engine, SAE transactions, pp. 93-120, 1982.

\section{НАПРЕДНИ МОДЕЛ УПРАВЉАЫА ЕНЕРГИЈОМ ЗАСНОВАН НА ПРАВИЛИМА ЗА ПОБОЉШАҢЕ ЕКОНОМИЧНОСТИ ХИБРИДНИХ ЕЛЕКТРИЧНИХ ГУСЕНИЧНИХ ВОЗИЛА}

\section{С.В. Милићевић, И.А. Благојевић, С.Р. Муждека}

Сва недавна технолошка достигнућа на пољу расподеле снаге између погонских агрегата у хибридним гусеничним возилима су углавном тешко примењива и тешка за израчунавање што их чини непрактичним за примену у стварном времену. У овом раду предложена је нова стратегија управљања паралелним хибридним електричним гусеничним возилима заснована на робусној и једноставној термостатској стратегији са додатком неких карактеристика power-follower стратегије (PFCS). Циљ стратегије управљања је смањење потрошње горива. Као референтно возило изабрано је борбено возило пешадије БВП М80-А домаће производње. У сврху валидације, у Simulink окружењу је креиран (backward-looking) модел реалног возила. Анализа резултата показује да предложена стратегија управљања омогућава уштеду горива од $12,8 \%$, а истовремено ефикасно одржава стање напуњености батерије (SOC). Још бољи резултати $(23,2 \%)$ постигнути су применом предложене стратегије на моделу са додатим генератором за допуну батерије. Закључено је да се додатна побољшања могу постићи комбинованом оптимизацијом конструкционих параметара возила и параметара модела управљања. 